\title{
Effect of plant protection on the production of hydroponic lettuce (Lactuca sativa convar. capitata $\mathrm{L}$.)
}

\author{
V. J. Vojnich*, J. Pető, A. Hüvely \\ John von Neumann University, Faculty of Horticulture and Rural Development, Department of Agricultural Sciences, \\ Mészöly Gyula Square 1-3, 6000 Kecskemét, Hungary, *e-mail: vojnich.viktor@kvk.uni-neumann.hu
}

\begin{abstract}
Purpose. In our experiment, the hydroculture cultivation of lettuce (Lactuca sativa convar. capitata L.) was studied under various Mg treatments, and we used pesticide protection against cotton bollworm (Helicoverpa armigera). Methods. The biometric evaluations were calculation with variance analysis (Tukey-HSD method and the statistical tests were performed using SPSS v19 software). Results. Our results observations that plant protections (Actara 240 SC, tiametoxam) were successfully contra Helicoverpa armigera. The recording time ( 94 pieces $H$. armigera) was on $5^{\text {th }}$ October 2015. The number of lettuces infected with the worms of the cotton bollworm was 9 (total) of end the research. When the lettuce was harvested (29th October), we measured the weight of lettuces, counting the number of caterpillars of $H$. armigera and analysing variance on the calculation. The most infected lettuces with the caterpillar were calculated in the 150 and $200 \mathrm{mg} / \mathrm{L} \mathrm{Mg}$ treatments. We measured 28 plants from each treatment area. The highest lettuce weight was found in the control group (186.1 g), while the lowest was among the $250 \mathrm{mg} / \mathrm{L}$ magnesium treatment. A Tukey statistical analysis was summarized. Conclusions. Despite the widely and commonly used traditional agricultural production technologies, hydroponic growing also has a great role in nowadays and in the future as well. In the course of our experiment we found that the easily purchased materials (rock wool, medium raw material) can be used costeffectively in the hydroponic cultivation. Based on our results we found that the effect of plant protection (Actara $240 \mathrm{SC}, 21.1 \% \mathrm{w} / \mathrm{v}$ thiamethoxam) was successful against cotton bollworm. Overall, the effect of insecticide treatments against Helicoverpa armigera protection was successful; the $56 \%$ infection on $5^{\text {th }}$ October was reduced to a $5 \%$ infection level on $29^{\text {th }}$ October. The lettuce was grown using hydroponic cultivation in our study. Their growth was steady, but there was a great deviation in head weight. While measuring the hydroponic lettuce we found that the magnesium treatment led to a significant decrease in head weight, compared to the control group.
\end{abstract}

Keywords: Lactuca sativa convar. capitata L.; hydroponic; plant protection; Actara 240 SC; lettuce yield.

\section{Introduction}

Nowadays hydroponics cultivation is very popular. Göhler and Molitor [1] prepared to divide one of the most comprehensive methods. During the improvement of hydroponic cultivation, several kinds of application methods have been developed for vegetable production. According to the composition of the substrate, organic and inorganic cultivation can be distinguished. The inorganic occurring cultivation listed cultivation with rock wool, calcined clay balls, plastic sponges, perlites, pebbles, and polystyrene pellets, which may take place in culture vessels. Environmental regulations are getting stricter, allowing only closed operation. Operating the system requires greater professional skills, continuous monitoring and attention is required. Periodically check the EC value, $\mathrm{pH}$, oxygen content, nutrient composition, contamination, and temperature [2].

Lettuce became from a seasonal vegetable into an all-year grown food having a wide range of species. Modern technologies, by using hydroponic lettuce growing, permit continuous cultivation of lettuce for 12 months every year [3-4]. The average consumption of the plant increased during the previous decade, so it can be inserted into modern healthy nourishment. Lettuce (Lactuca sativa convar. capitata L.) is a significant vegetable, rich in vitamins and minerals as well. Growing in hydroculture has several beneficial advantages compared to the soil growing as regard of: faster development, higher average of yield,

Vojnich, V. J., Pető, J., \& Hüvely, A. (2018). Effect of plant protection on the production of hydroponic lettuce (Lactuca sativa convar. capitata L.). Novitnì agrotehnologiï [Advanced agritechnologies], 6. Retrieved from http://jna.bio.gov.ua/article/view/165364. 
balanced and schemed development. Furthermore, growing can be automated by electric technologies, in an environmentally friendly way, and the production does not require significant manual labour [5-6].

By the use of an automated (electronic technology) system, the nutrient solution can circulate several times a day in the hydroculture channel system [7-13].

Magnesium is a central component of chlorophyll, which has a unique role in photosynthesis; magnesium is an essential metal in the plant metabolism, protein biosynthesis, and collaborates as a metallic catalyst in take and release of energy [14-21].

It can influence the development of plants with low or high humidity. The optimum humidity is $70 \%$ [22]. The optimal growth of lettuce depends on the temperature. If there is no continuous air exchange, the vapour and oxygen build up, thus assimilation will deteriorate and eventually stop [23]. Due to the sensitivity of the lettuce, the drying of the rock wool may damage the root feel. For economic reasons, $4 \times 4$ or $5 \times 5$ rock wool is used for seedlings [24].

In our experiment, the hydroculture cultivation of lettuce (Lactuca sativa convar. capitata L.) was studied under various $\mathrm{Mg}$ treatments, and we used pesticide protection against cotton bollworm (Helicoverpa armigera).

\section{Materials and methods}

The experiment was carried out in the greenhouse of the John von Neumann University, Faculty of Horticulture and Rural Development in autumn 2015. A small air-space, $6.4 \mathrm{~m}$ wide and $6.4 \mathrm{~m}$ long in a closed area, three hydroponics table, in the cultivation channels dedicated Groden Delta rock wool performed lettuce experiments begin. Experimental plants were propagated by seeding and subsequent transplant raising in greenhouse. The lettuce seedlings were placed into rock cotton cubes, and put into hydroponic growing channels. The level of heating the greenhouse at $15-20^{\circ} \mathrm{C}$. The lettuce seed was thrown into the cell feeding tray on $24^{\text {th }}$ August 2015. The seedlings of the Groden Delta rock wool were placed on $4^{\text {th }}$ September 2015. The water-soluble fertilizer was measured by a digital laboratory scale. Treatments used in the experiment: control, 50-, 100-, 150-, 200- and $250 \mathrm{mg} / \mathrm{L}$ of magnesium treatments. Magnesium fertilizer data for the experiment: Magnisal fertilizer (active substance content $\mathrm{N} 11 \%, \mathrm{MgO}$ $15 \%)$. It is very soluble in water. Medium: 1 litre of distilled water was added 310 grams of Magnisal fertilizer. This medium was measured for treatments $(50 \mathrm{mg} / \mathrm{L} \mathrm{Mg}$ treatment with $50 \mathrm{ml}$ medium; $100 \mathrm{mg} / \mathrm{L} \mathrm{Mg}$ treatment with $100 \mathrm{ml}$ medium; $150 \mathrm{mg} / \mathrm{L} \mathrm{Mg}$ treatment with $150 \mathrm{ml}$ medium; $200 \mathrm{mg} / \mathrm{L}$ $\mathrm{Mg}$ treatment with $200 \mathrm{ml}$ medium; $250 \mathrm{mg} / \mathrm{L} \mathrm{Mg}$ treatment with $250 \mathrm{ml}$ medium). Each channel of the closed nutrient system had a separate container with a separate submersible pump to ensure adequate circulation of the nutrient solution for plants. The number of plants per plot was 28. The experimental design was a randomized blocks with 4 repetitions. In each treatment 7 plants were measured. The 28 litre container containing the hydroculture channels was filled with the medium which was exchanged once a week. The submersible pump device in the tanks circulated the nutrient solution three times a day in the system.

The temperature control is adjusted according to the recommendation, with a thermostat automatically. During the day, we adjusted the temperature by compensating for the heat of the sunshine by manually opening and closing the ventilators.

On $5^{\text {th }}$ October 2015, we noticed that the lettuce was damaged by the cotton bollworm (Helicoverpa armigera) larva. Probably during the ventilation it was possible for the pests to settle on the lettuces. On $8^{\text {th }}$ October 2015 Actara $240 \mathrm{SC}(21.1 \% \mathrm{~m} / \mathrm{m}$ thiamethoxam $)$ insecticide spray was sprayed onto the lettuce. Harvest of lettuce was made on $29^{\text {th }}$ October 2015, we measured the fresh weight of lettuce. The evaluation of the lettuce data infected with the worms of the cotton bollworm was carried out using the Tukey-HSD method and the statistical tests were performed using SPSS v19 software. The mean difference is significant at the 0.05 level [25]. Following harvest, the leaves of lettuce were dried in a LTE-OP-250 drying oven in the laboratory. In the course of the experiment, the nutrient element concentrations nitrogen, magnesium and calcium were determined in the leaves of lettuce.

\section{Results}

We can show the number of lettuces infected with caterpillar of the cotton bollworm (Table 1). The most infected lettuces with the caterpillar were calculated in the 150 and $200 \mathrm{mg} / \mathrm{L} \mathrm{Mg}$ treatments $(26$ and 23). The recording time (94 pieces $H$. armigera) was on $5^{\text {th }}$ October 2015 . The Table 2 presents the significance values of the Tukey-HSD method. The 50 and $100 \mathrm{mg} / \mathrm{L} \mathrm{Mg}$ treatments were not significant. 
Effect of plant protection on the production of hydroponic lettuce (Lactuca sativa convar. capitata L.)

Table 1

Number of Helicoverpa armigera caterpillars on the lettuce head before plant protection

\begin{tabular}{lcccc}
\hline Treatments & $\begin{array}{c}\text { Total lettuce } \\
\text { (number) }\end{array}$ & $\begin{array}{c}\text { Lettuces infected with caterpillars } \\
\text { of cotton bollworm (number) }\end{array}$ & Mean & St. Error \\
\hline Control & 28 & 6 & 0.2143 & 0.41786 \\
$50 \mathrm{mg} / \mathrm{L} \mathrm{Mg}$ & 28 & 10 & 0.3571 & 0.48795 \\
$100 \mathrm{mg} / \mathrm{L} \mathrm{Mg}$ & 28 & 13 & 0.4643 & 0.50787 \\
$150 \mathrm{mg} / \mathrm{L} \mathrm{Mg}$ & 28 & 26 & 0.9286 & 0.26227 \\
$200 \mathrm{mg} / \mathrm{L} \mathrm{Mg}$ & 28 & 23 & 0.8214 & 0.39002 \\
$250 \mathrm{mg} / \mathrm{L} \mathrm{Mg}$ & 28 & 16 & 0.5714 & 0.50395 \\
Total & 168 & 94 & 0.5595 & 0.49793 \\
\hline
\end{tabular}

Tukey-HSD test of significance measurement

Table 2

(parameter: H. armigera caterpillars on the lettuce head before plant protection)

\begin{tabular}{ccccc}
\hline $\begin{array}{c}\text { Treatments } \\
(\mathrm{A})\end{array}$ & Treatments & $\begin{array}{c}\text { Mean difference } \\
(\mathrm{A}-\mathrm{B})\end{array}$ & St. Error & Significance \\
\hline Control & (B) & -0.14286 n.s. & 0.11678 & 0.825 \\
& $50 \mathrm{mg} / \mathrm{L} \mathrm{Mg}$ & -0.25000 n.s. & 0.11678 & 0.272 \\
& $100 \mathrm{mg} / \mathrm{L} \mathrm{Mg}$ & $-0.71429^{*}$ & 0.11678 & 0.000 \\
& $150 \mathrm{mg} / \mathrm{L} \mathrm{Mg}$ & $-0.60714^{*}$ & 0.11678 & 0.000 \\
& $200 \mathrm{mg} / \mathrm{L} \mathrm{Mg}$ & $-0.35714^{*}$ & 0.11678 & 0.031 \\
\hline
\end{tabular}

* The mean difference is significant at the 0.05 level.

n.s. = not significant

When harvesting lettuce (29th October 2015) we measured the weight of the lettuces, counting the number of caterpillars of $\mathrm{H}$. armigera by repetition and treatment (Table 3 ), and a variance analysis was made on the calculation (Table 4).

Table 3

Number of Helicoverpa armigera caterpillars in the lettuce head after plant protection

\begin{tabular}{lcccc}
\hline Treatments & $\begin{array}{c}\text { Total lettuce } \\
\text { (number) }\end{array}$ & $\begin{array}{c}\text { Lettuces infected with caterpillars } \\
\text { of cotton bollworm (number) }\end{array}$ & Mean & St. Error \\
\hline Control & 28 & 0 & 0.0000 & 0.00000 \\
$50 \mathrm{mg} / \mathrm{L} \mathrm{Mg}$ & 28 & 1 & 0.0357 & 0.18898 \\
$100 \mathrm{mg} / \mathrm{L} \mathrm{Mg}$ & 28 & 0 & 0.0000 & 0.00000 \\
$150 \mathrm{mg} / \mathrm{L} \mathrm{Mg}$ & 28 & 6 & 0.2143 & 0.41786 \\
$200 \mathrm{mg} / \mathrm{L} \mathrm{Mg}$ & 28 & 0 & 0.0000 & 0.00000 \\
$250 \mathrm{mg} / \mathrm{L} \mathrm{Mg}$ & 28 & 2 & 0.1071 & 0.31497 \\
Total & 168 & 9 & 0.0595 & 0.23731 \\
\hline
\end{tabular}

Tukey-HSD test of significance measurement

Table 4

(parameter: H. armigera caterpillars on the lettuce head after plant protection)

\begin{tabular}{ccccc}
\hline $\begin{array}{c}\text { Treatments } \\
(\mathrm{A})\end{array}$ & $\begin{array}{c}\text { Treatments } \\
\text { (B) }\end{array}$ & $\begin{array}{c}\text { Mean difference } \\
(\mathrm{A}-\mathrm{B})\end{array}$ & St. Error & Significance \\
\hline Control & $50 \mathrm{mg} / \mathrm{L} \mathrm{Mg}$ & -0.03571 n.s. & 0.06070 & 0.992 \\
& $100 \mathrm{mg} / \mathrm{L} \mathrm{Mg}$ & 0.00000 n.s. & 0.06070 & 1.000 \\
& $150 \mathrm{mg} / \mathrm{L} \mathrm{Mg}$ & $-0.21429^{*}$ & 0.06070 & 0.007 \\
& $200 \mathrm{mg} / \mathrm{L} \mathrm{Mg}$ & 0.00000 n.s. & 0.06070 & 1.000 \\
& $250 \mathrm{mg} / \mathrm{L} \mathrm{Mg}$ & -0.10714 n.s. & 0.06070 & 0.491 \\
\hline
\end{tabular}

* The mean difference is significant at the 0.05 level.

n.s. = not significant 
After plant protection, the number of cotton bollworm decreased to 9 (Table 3). Only the $150 \mathrm{mg} / \mathrm{L} \mathrm{Mg}$ treatment was significant (Table 4), because the value was 0.007 (the mean difference is significant at the 0.05 level).

We measured 28 plants from each treatment area. The highest lettuce weight was found in the control group $(186.1 \mathrm{~g})$, while the lowest was among the $250 \mathrm{mg} / \mathrm{L}$ magnesium treatment. Tukey statistical analysis were summarise in Table 5.

Tukey HSD test of lettuce (parameter: lettuce head weight)

\begin{tabular}{cccccc}
\hline $\begin{array}{c}\text { Treatments } \\
(\mathrm{A})\end{array}$ & $\begin{array}{c}\text { Treatments } \\
\text { (B) }\end{array}$ & $\begin{array}{c}\text { Mean difference } \\
(\mathrm{A}-\mathrm{B})\end{array}$ & St. Error & $\begin{array}{c}\text { Significance } \\
\text { level }\end{array}$ & $\begin{array}{c}\text { Wet weight } \\
(\mathrm{g})\end{array}$ \\
\hline Control & $50 \mathrm{mg} / \mathrm{L} \mathrm{Mg}$ & $54.89^{*}$ & 6.904 & 0.000 & 132.3 \\
& $100 \mathrm{mg} / \mathrm{L} \mathrm{Mg}$ & $29.11^{*}$ & 6.904 & 0.001 & 131.4 \\
& $150 \mathrm{mg} / \mathrm{L} \mathrm{Mg}$ & $75.46^{*}$ & 6.904 & 0.000 & 111.6 \\
& $200 \mathrm{mg} / \mathrm{L} \mathrm{Mg}$ & $67.96^{*}$ & 6.904 & 0.000 & 117.1 \\
& $250 \mathrm{mg} / \mathrm{L} \mathrm{Mg}$ & $77.43^{*}$ & 6.904 & 0.000 & 104.1 \\
\hline
\end{tabular}

*The mean difference is significant at the 0.05 level.

n.s. = not significant

In the course of the experiment, the nutrient element concentrations nitrogen, magnesium and calcium were determined in the leaves of lettuce (Figure 1).

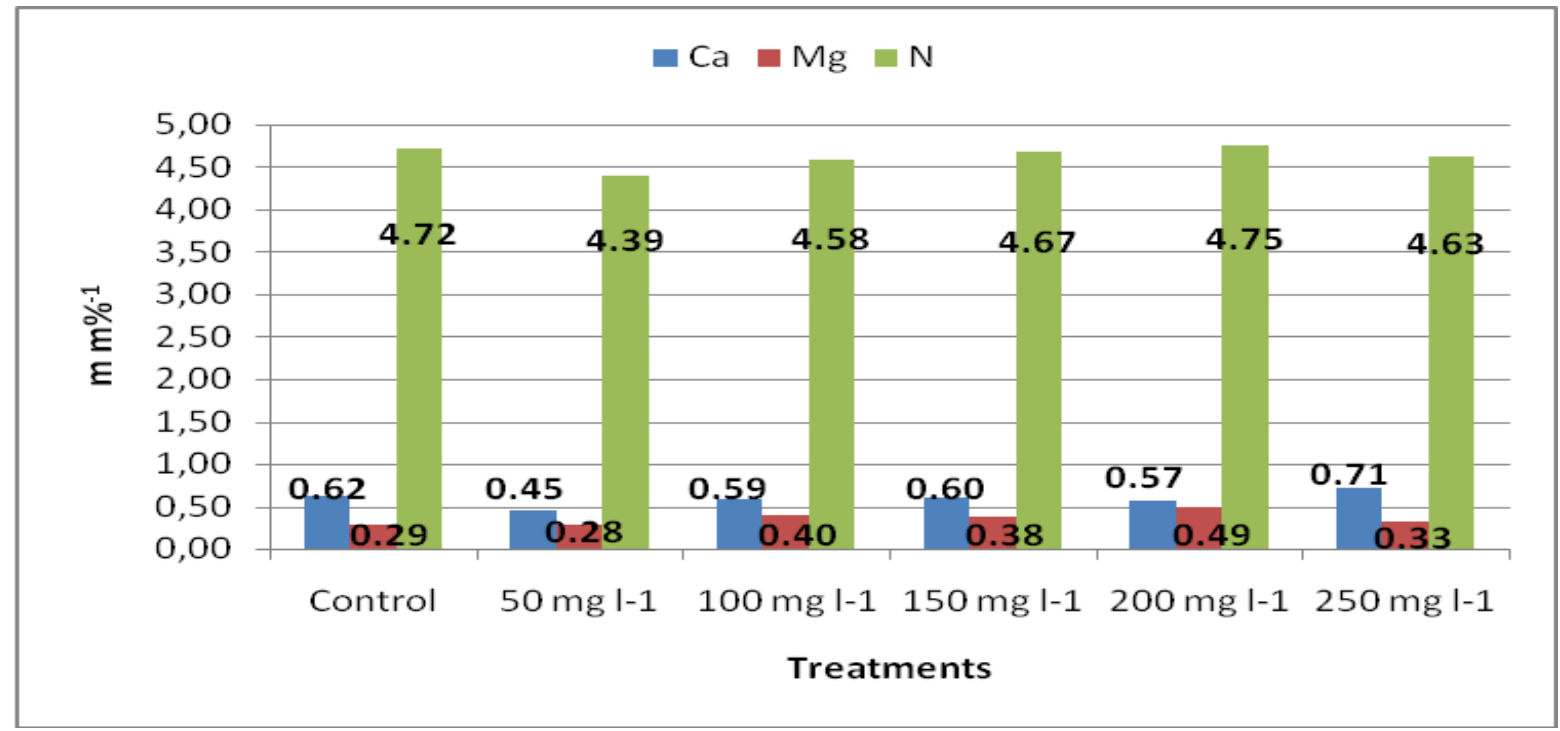

Figure 1. The nutrient element concentration $(\mathrm{Ca}, \mathrm{Mg}, \mathrm{N})$ in the leaves of lettuce

The increasing magnesium concentration in the nutriment solution caused the decrease of nitrogen content of dry matter in the leaves from $4.72 \mathrm{~m} / \mathrm{m} \%$ to $4.63 \mathrm{~m} / \mathrm{m} \%$. The concentration of magnesium increased from $0.29 \mathrm{~m} / \mathrm{m} \%$ to $0.49 \mathrm{~m} / \mathrm{m} \%$. The calcium concentration was decreased from $0.62 \mathrm{~m} / \mathrm{m} \%$ to $0.71 \mathrm{~m} / \mathrm{m} \%$, in the average of repetitions.

\section{Conclusions}

Despite the widely and commonly used traditional agricultural production technologies, hydroponic growing also has a great role in nowadays and in the future as well. In the course of our experiment we found that the easily purchased materials (rock wool, medium raw material) can be used cost-effectively in the hydroponic cultivation.

Human labor is only needed for planting into stone wool, filling in the nutrient solution and harvesting. More work is needed for production on a field. In the case of hydroponic growing there is no need for weeding, fertilizing or groundwork. The leaves turning brown and rotting can be avoided with using adequate nutrient solutions. Higher salt concentration or excessive nutrient ratios may easily cause inadequate growing or disorders. 
The lettuce was grown using hydroponic cultivation in our study. Their growth was steady, but there was a great deviation in head weight. While measuring the hydroponic lettuce we found that the magnesium treatment led to a significant decrease in head weight, compared to the control group. The highest lettuce weight was found in the control group $(186.1 \mathrm{~g})$, while the lowest $(104.1 \mathrm{~g})$ was among the $250 \mathrm{mg} / \mathrm{L}$ magnesium treatment.

Based on our results we found that the effect of plant protection (Actara $240 \mathrm{SC}, 21.1 \% \mathrm{w} / \mathrm{v}$ thiamethoxam) was successful against cotton bollworm. Magnesium treatments were used in our experiment. Magnesium is a central component of chlorophyll, which has a unique role in photosynthesis; magnesium is an essential metal in the plant metabolism, protein biosynthesis, and collaborates as a metallic catalyst in take and release of energy. The most infected lettuces with the caterpillar were calculated in the 150 and $200 \mathrm{mg} / \mathrm{L} \mathrm{Mg}$ treatments. Overall, the effect of insecticide treatments against Helicoverpa armigera defence was successful; the $56 \%$ infection on $5^{\text {th }}$ October was reduced to a $5 \%$ infection level on 29th October.

\section{Acknowledgment}

This research is supported by EFOP-3.6.1-16-2016-00006 "The development and enhancement of the research potential at John von Neumann University" project. The Project is supported by the Hungarian Government and co-financed by the European Social Fund.

\section{References}

1. Göhler, F., \& Molitor, H. D. (2002). Erdelose Kulturverfahren im Gartenbau [Earthless culture in horticulture]. Stuttgart: Eugen Ulmer Verlag. [in German]

2. Kovács, A. (2000). Talaj nélküli termesztés. A zöldséghajtatás kézikönyve [Cultivation without soil. Vegetable Handbook]. Budapest: Mezőgazda Kiadó. [in Hungarian]

3. Ferencz, Á., \& Marselek, S. (2008). Agronomy. In Nábrádi, A. Pupos, T. Takácsné, \& K. Gy. (Eds.), Organisation and economy of vegetable (pp. 88-115). Budapest: Expertise Publishing House.

4. Nótári, M., \& Ferencz, Á. (2013). Harmonizing quality criteria of regional horticultural products and customers' decision in Hungary. Procedia-Social and Behavioral Sciences, 81, 672-677. doi: 10.1016/j.sbspro.2013.06.494

5. Kovács, A. (2005). Vízkultúrás és konténeres termesztés [Waterculture and Container Growing]. In Terbe, I., Hodossi, S., \& Kovács, A., Zöldségtermesztés termesztő berendezésekben [Vegetable growing equipment]. Budapest: Mezőgazda Kiadó. [in Hungarian]

6. Terbe, I. (2005). Zöldségtermesztés termesztóberendezésekben [Leaf vegetables forcing] (pp.191-199). Budapest: Mezőgazdasági Kiadó. [in Hungarian]

7. Budai, Cs. (2002). Növényvédelem a zöldséghajtatásban [Plant protection in vegetable forcing]. Budapest: Mezőgazdasági Kiadó. [in Hungarian]. [in Hungarian]

8. Hüvely, A., Buzás, I., Borsné Pető, J., \& Tóthné Taskovics, Zs. (2011). Examination of the arsenic accumulating capacity of lettuce growing in aggregate hydroponics under the influence of arsenic polluted nutrient solution. Acta Universitatis Sapientiae, Agriculture and Environment, 3, 122-131.

9. Ledóné, D. H. (2012). Saláta termesztés Magyarországon [Lettuce cultivation in Hungary]. Zöldség-Gyümölcs. Piac és Technológia, 16(11-12), 14-15. [in Hungarian]

10. Morgan, L. (1999). Hydroponic lettuce production. Narrabeen, Australia: Casper Publications.

11. Terbe, I., \& Slezák, K. (2008). Talaj nélküli zöldséghajtatás [Vegetables forcing without soil] (pp. 10-19). Budapest Mezőgazda: Kiadó. [in Hungarian]

12. Resh, H. M. (2012). Hydroponic Food Production: A Definitive Guidebook for the Advanced Home Gardener and the Commercial Hydroponic Grower. (7th Ed.). Boca Raton, FL: CRC Press.

13. Tömpe, A. (2014). Kísérleti termesztőrendszer [Experimental production system]. Kertészet és Szôlészet, 63(6), 8-9. [in Hungarian]

14. Terbe, I. (2007). A saláta tápanyagellátása [Nutrient supply of lettuce]. Kertészeti és Szőlészeti, 56(10), 10-12. [in Hungarian]

15. Terbe, I., Slezák, K., \& Kapel, N. (2011). Kertészeti és szántóföldi növények fejlődési rendellenességei [Anomaly development of horticulture and arable crops]. Budapest: Mezőgazda Kiadó. [in Hungarian]

16. Terbe, I., Slezák, K., Kappel, N., \& Tóth, K. (2001). A termésminőség és tápanyagellátás összefüggése a zöldségtermesztésben [Fruit quality and nutrient supply relationship between in the cultivation of vegetables]. Integrált termesztés a kertészeti és a szántóföldi kultúrákban XXII. Növény és Talajvédelmi Központi Szolgálat [Integrated production of horticultural and arable crops. XXII. Plant and Soil Protection Service] (pp. 83-93). November 27. Budapest. [in Hungarian] 
17. Zsom, E. (2009). A kálium, a magnézium és kén szerepe a zöldségtermesztésben [The role of potassium, magnesium and sulfur in vegetable production]. Agrárágazat, 20(3), 8. [in Hungarian]

18. Terbe, I. (2013). Magnézium-hiánytünetek zöldségféléken és gyümölcsön [Magnesium deficiency syndrome on vegetables and fruits]. Agroinform, 22(4), 12-13. [in Hungarian]

19. Terbe, I. (2012). Szinergisták vagy antagonisták [Synergists or antagonists]. Agrofórum, 23(4), 122. [in Hungarian]

20. Terbe, I. (2011). Kertészeti és szántóföldi növények fejlődési rendellenességei [Developmental disorders of horticultural and arable crops] (pp. 119-120, 126). Budapest: Mezőgazdasági Kiadó. [in Hungarian]

21. Horinka, T., \& Knipf, R. (2007). Zöldségnövények hiánybetegségei és klimatikus hatások tünetei [Diseases of the lack of vegetables]. Mórahalom: Kertészek Kis Nagy Áruháza Kft. [in Hungarian]

22. Cselőtei, L. (1997). A zöldségnövények öntözése [Irrigation of vegetable plants] (p. 172). Budapest: Mezőgazda Kiadó. [in Hungarian]

23. Terbe, I., Slezák, K., Kappel, N., \& Tóth, K. (2001). A termésminőség és tápanyagellátás összefüggése a zöldségtermesztésben [The relationship between quality and nutrition in vegetable production]. Integrált termesztés a kertészeti és a szántóföldi kultúrákban XXII. Növény és Talajvédelmi Központi Szolgálat [Integrated cultivation in horticultural and arable crops XXII. Plant and Soil Protection Central Service] (pp. 83-93). Budapest: N.p. [in Hungarian]

24. Tompos, D. (2008). A fejes saláta talaj nélküli termesztése [Cultivation of lettuce without soil]. Budapest: Mezőgazda Kiadó. [in Hungarian]

25. Huzsvai, L. (2004). Biometriai módszerek az SPSS-ben. SPSS alkalmazások [Biometric methods in SPSS. Textbook] (pp. 65-66). Debrecen: Debreceni Egyetem. [in Hungarian]

\section{УДК 635.521. 632.951.1.635-18}

Vojnich V.J., Pető J., Hüvely A. Вплив системи захисту рослин на вирощування гідропонного салату (Lactuca sativa convar. capitata L.). Новітні агротехнологіï. $2018 . \quad$ № $6 . \quad$ URL: http://jna.bio.gov.ua/article/view/165364.

Університет Джона фон Неймана, Факультет овочівництва й розвитку сільськогосподарських районів, кафедра сільськогосподарських наук, площа Дьюла Месцолі, 1-3, Кечкемет, , 6000, Угорщина *e-mail: vojnich.viktor@kvk.uni-neumann.hu

Мета. У нашому експерименті культивування гідрокультури салату (Lactuca sativa convar. capitata L.) вивчалося за різних режимів $\mathrm{Mg}$, а також ми використовували пестициди проти бавовникової совки (Helicoverpa armigera). Методи. Біометричні вимірювання виконували з аналізом дисперсії (метод ТикеуHSD, статистичні тести проводили з використанням програмного забезпечення SPSS v19. Результати. Наші результати свідчать про те, що система захисту рослин (препарат Actara 240 SC, д.р. тіаметоксам) була успішно використана проти Helicoverpa armigera. Кількість головок салату, заражених бавовниковою совкою становила 9 (загальна кількість). Час обліку (94 одиниць H. armigera) результатів 5 жовтня 2015 року. Кількість головок салату, заражених бавовниковою совкою, складала 9 (всього) у кінці досліджень. На час збору врожаю (29 жовтня), ми виміряли вагу головок салату, підрахувавши кількість гусениць H. armigera та проаналізували відхилення в розрахунках. Найбільшу кількість заражених головок салату було зафіксовано з режимами Mg 150 і 200 мг/л. Ми виміряли 28 рослин з кожного режиму Mg з різними концентраціями. Найбільше значення маси головки салату було визначено в контрольній групі (186 г), а найнижче за магнієвої обробки 250 мг/л. Отримані дані були оцінені за допомогою статистичного аналізу Tukey-HSD. Висновки. Незважаючи на широко поширені традиційні технології сільськогосподарського виробництва, гідропонне вирощування також відіграє велику роль і в наші дні, і в майбутньому. У процесі експерименту ми виявили, що матеріали, які знаходяться у вільному продажу (кам'яна вата, сировинний матеріал) можна економічно ефективно використовувати за гідропонного культивування. На основі результатів наших досліджень визначено, що вплив системи захисту (Actara 240 SC, 21.1\% г/мл, д.р. тіаметоксам) виявився ефективним проти бавовникової совки. Загалом, ефект від впливу інсектициду проти Helicoverpa armigera був успішним; 56-відсоткова зараженість 5 жовтня було знижено до 5 \%-го рівня інфікування 29 жовтня. У наших дослідженнях салат вирощували 3 використанням гідропонної культивації. Ріст салату був стабільним, але спостерігалося значне відхилення у вазі головки. Відповідно до показників вимірювань гідропонного салату, ми виявили, що обробка магнієм привела до значного зниження ваги головки салату в порівнянні з контрольною групою.

Ключові слова: Lactuca sativa convar. capitata L.; гідропоніка; захист рослин; Actara 240 SC; урожай салату.

УДК 635.521. 632.951.1.635-18

Vojnich V. J. , Pető J., Hüvely A. Влияние системы защиты растений на выращивание гидропонного салата (Lactuca sativa convar. capitata L.) // Новітні агротехнології. $2018 . \quad$ № $6 . \quad$ URL: http://jna.bio.gov.ua/article/view/165364. 
Университет Джона фон Неймана, Факультет овощеводства и развития сельскохозяйственных районов, кафедра сельскохозяйственных наук, площадь Дьюла Месцоли, 1-3, Кечкемет, 6000, Венгрия

*e-mail: vojnich.viktor@kvk.uni-neumann.hu

Цель. В нашем эксперименте культивирование гидрокультуры салата-латука (Lactuca sativa convar. Capitata L.) изучалось при различных режимах Mg, а также мы использовали пестициды против хлопоковой совки (Helicoverpa armigera). Методы. Биометрические измерения были произведены с анализом дисперсии (метод Tukey-HSD, статистические тесты были выполнены с использованием программного обеспечения SPSS v19). Результаты. Наши результаты свидетельствуют о том, что система защиты растений (препарат Actara 240 SC, д.в. тиаметоксам) была успешно использована против Helicoverpa armigera. Количество головок салата, зараженных хлопковой совкой составило 9 (общее количество). Время учета (94 единиц H. armigera) результатов - 5 октября 2015 года. Количество головок салата, заражённых хлопковой совкой, составило 9 (всего) в конце исследований. Во время сбора урожая (29 октября), мы измерили вес головок салата, подсчитав количество гусениц H. armigera и проанализировали отклонения в расчетах. Наибольшее количество зараженных головок салата было зафиксировано с режимами Mg 150 и 200 мг/л. Мы измерили 28 растений из каждого режима Mg с разными концентрациями. Наибольшее значение массы головки салата было определено в контрольной группе (186 г), а самое низкое - при магниевой обработке 250 мг/л. Полученные данные были оценены с помощью статистического анализа Tukey-HSD. Bыводы. Несмотря на широко распространенные традиционные технологии сельскохозяйственного производства, гидропонное выращивание также играет большую роль и в наши дни, и в будущем. В ходе нашего эксперимента мы обнаружили, что материалы, которые находятся в свободной продаже (каменная вата, сырьевой материал) можно экономически эффективно использовать при гидропонном культивировании. На основе результатов исследований определено, что влияние системы защиты (Actara 240 SC, 21.1 \% г/мл, д.в. тиаметоксам) оказалось эффективным против хлопковой совки. В целом, эффект от воздействия инсектицидами против Helicoverpa armigera был успешным; $56 \%$-ная зараженность 5 октября была снижена до 5 \%-го уровня инфицирования 29 октября. В наших исследованиях салат-латук выращивали с использованием гидропонной культивации. Рост салата был стабильным, но наблюдалось значительное отклонение в весе головки. В соответствии с показателями измерений гидропонного салата, мы обнаружили, что обработка магнием привела к значительному снижению веса головки салата по сравнению с контрольной группой.

Ключевые слова: Lactuca sativa convar. capitata L.; гидропоника; защита растений; Actara 240 SC; урожай салата.

Надійшла / Received 02.11.2018

Погоджено до друку / Accepted 28.11.2018 